\title{
Pengaruh Intensitas Cahaya dan Nutrisi Terhadap Pertumbuhan Miselium Pleurotus ostreatus di Tangerang
}

\author{
GERVASIUS HARWIN WANGRIMEN ${ }^{1}$, FERDIAN ${ }^{1}$, MEYTA VALENTINE $^{2}$, YASHINTA \\ BUDIYANTI $^{2}$, INDAH JUWITA SARI ${ }^{3}$ \\ ${ }^{1}$ Program Studi Nutrition Food Technology, Fakultas Life Science, Universitas Surya Kampus Hub, \\ Grand Serpong Mall lantai 1 unit F8 \& F9 \\ Jl. M.H.Thamrin Km 2.7, Panunggangan Utara, Pinang, Tangerang. 15143 \\ ${ }^{2}$ Program Studi Biotechnology and Neuroscience, Fakultas Life Science, Universitas Surya Kampus \\ Hub, Grand Serpong Mall lantai 1 unit F8 \& F9 \\ Jl. M.H.Thamrin Km 2.7, Panunggangan Utara, Pinang, Tangerang. 15143 \\ ${ }^{3}$ Pendidikan Biologi, Fakultas Keguruan dan Ilmu Pendidikan, Universitas Sultan Ageng Tirtayasa \\ Jl. Ciwaru Raya Serang, Banten, Jawa Barat. 42117 \\ Email: indah.juwitasari@gmail.com
}

Received 10 December 2017; Received in revised form 19 January 2018; Accepted 2 February 2018; Available online 3 February 2018

\begin{abstract}
White oyster mushroom (Pleurotus ostreatus) is a type of beneficial mushroom, widely used for consumption, medicinal ingredients, as well as business-oriented cultivation. Nutrition and light intensity are two of the most influential factors for the growth of white oyster mushroom mycelium. Nutrients such as water used for rice cooking (traditionally called air leri) and glucose solution are thought to be potential sources of nutrients, but it is not known which nutrients are more suitable for the growth of white oyster mushroom mycelium. This research was conducted to find out the growth rate difference of white oyster mushroom mycelium produced by vary LED (Light-Emitting Diode) light intensity (sequentially 0 lux, $10^{3} \mathrm{lux}, 2 \times 10^{3} \mathrm{lux}, 3 \times 10^{3} \mathrm{lux}$, and $4 \times 10^{3} \mathrm{lux}$ ), air leri nutrition with a 1:1 dilution ratio, glucose solution with 1:3 ratio. Processed data showed that the growth rate of white oyster mushroom mycelium with air leri nutrition for 18 days is better than glucose solution, while low light intensity will affect the color to the growth rate of mycelium on the bag log medium.
\end{abstract}

Keywords: air leri, glucose, light intensity, mycelium, Pleurotus ostreatus

\section{INTISARI}

Jamur tiram putih (Pleurotus ostreatus) merupakan salah satu jenis jamur yang kaya manfaat, dan banyak digunakan untuk konsumsi, bahan pengobatan, maupun budidaya bisnis. Nutrisi dan intensitas cahaya merupakan beberapa faktor yang sangat berpengaruh bagi pertumbuhan miselium jamur tiram putih. Nutrisi seperti air leri dan larutan glukosa diduga berpotensi untuk dijadikan sebagai sumber nutrisi, namun belum diketahui nutrisi manakah yang lebih cocok untuk pertumbuhan miselium jamur tiram putih. Penelitian ini dilakukan untuk mengetahui perbandingan kecepatan tumbuh miselium jamur tiram putih yang dihasilkan oleh masing-masing intensitas cahaya lampu LED (Light-Emitting Diode) dengan perbedaan intensitas (secara berurutan adalah 0 lux, $10^{3}$ lux, $2 \times 10^{3}$ lux, $3 \times 10^{3}$ lux, $4 \times 10^{3}$ lux), dan nutrisi air leri dengan rasio pengenceran 1:1 dan glukosa 1:3. Pengolahan data menunjukkan bahwa kecepatan pertumbuhan miselium jamur tiram putih dengan nutrisi air leri selama 18 hari lebih baik dibandingkan dengan larutan glukosa dan intensitas cahaya yang rendah akan memengaruhi warna hingga kecepatan pertumbuhan miselium pada media tanam bag log.

Kata kunci: air leri, glukosa, intensitas cahaya, miselium, Pleurotus ostreatus 


\section{PENDAHULUAN}

Indonesia merupakan negara dengan tingkat kuliner yang bervariasi dari berbagai jenis makanan. Permintaan di sektor jamur tergolong cukup tinggi empat tahun terakhir. Pusat Data dan Sistem Informasi Pertanian (2015) menyatakan bahwa rata-rata pertumbuhan impor jamur ke luar negeri mencapai angka $37,62 \%$ pada tahun 20102014. Potensi impor jamur ke luar negeri dapat mengalami peningkatan. Selain dapat digunakan sebagai bahan makanan, jamur tiram putih juga dapat digunakan sebagai antibakteri dan anti-tumor sehingga dapat mengurangi risiko terjangkit berbagai penyakit seperti diabetes melitus dan penyempitan pembuluh darah, serta manfaat lain seperti menurunkan kolesterol darah dan meningkatkan daya tahan tubuh terhadap penyakit polio (Puspitasari $d k k$., 2014).

Pada bidang usaha, budidaya jamur tiram putih (Pleurotus ostreatus) banyak dimanfaatkan karena permintaan dari pasar yang terbilang cukup tinggi (Puspaningrum dan Suparti, 2010). Dalam melakukan budidaya tersebut, pertumbuhan dan perkembangan jamur tiram putih dipengaruhi oleh beberapa faktor, seperti intensitas cahaya, suhu, $\mathrm{pH}$, media tanam, dan kelembaban lingkungan (Ayu, 2016). Intensitas cahaya dan nutrisi yang tepat akan memengaruhi pertumbuhan jamur tiram. Intensitas cahaya yang optimum bagi jamur tiram yaitu intensitas cahaya rendah, atau bahkan tanpa adanya cahaya. Akan tetapi, pada saat fase tubuh buah dewasa jamur tiram putih tidak dapat tumbuh pada kondisi cahaya gelap, melainkan dapat tumbuh dengan optimal pada lingkungan yang agak terang. Pada intensitas cahaya yang langsung dipaparkan oleh sinar matahari, jamur tiram putih tidak dapat tumbuh, karena sinar tersebut akan menembus permukaan tubuh buah jamur dan akan menyebabkan kerusakan dan layu, sehingga jamur tiram yang tumbuh pada paparan langsung dari sinar matahari akan memiliki tudung yang relatif kecil dari normalnya (Tim Redaksi Trubus, 2010). Penelitian terdahulu yang dilakukan oleh Amelia $d k k$. (2017) mengenai pengaruh suhu dan intensitas cahaya terhadap pertumbuhan jamur tiram di Tangerang, diperoleh hasil terbaik untuk pertumbuhan jamur tiram berada pada suhu $28^{\circ} \mathrm{C}$ dengan pencahayaan menggunakan lampu sebesar 5 watt.

Jamur tiram putih memiliki beberapa fase pertumbuhan mulai dari pembentukan spora (basidiospora), miselium, dan pada fase primordial. Selanjutnya, bintil akan tumbuh menjadi tubuh buah dewasa. Perkembangan tubuh buah membutuhkan materi yang mengandung nutrisi yang disuplai oleh miselium (Wahidah dan Saputra, 2015) dan akan memiliki kemampuan untuk menghasilkan spora kembali (Aliffahrana, 2012).

Jamur tiram putih memerlukan beberapa unsur seperti karbon dan nitrogen, vitamin B1 (tiamin), B3 (niasin), B5 (asam pantotenat), B7 (biotin), dan vitamin $\mathrm{C}$ sebagai nutrisi pertumbuhannya, serta mineral lainnya. Pertumbuhan jamur tiram putih yang disertai dengan asupan mineral yang cukup, akan membuat jamur memiliki unsur nutrisi yang kaya yang ditandai dengan adanya kadar unsur pada miselium dan badan buah jamur (Sumarsih, 2015).

Beberapa bahan pangan yang dapat digunakan sebagai nutrisi bagi pertumbuhan jamur tiram diantaranya monosakarida glukosa dan air leri. Glukosa dapat memberikan pertumbuhan maksimum bagi jamur, karena glukosa lebih mudah diubah menjadi suatu fosforilasi derivatif yang dapat masuk ke sistem jalur respirasi (Yuanita, 2011).

Air leri atau yang disebut sebagai air cucian beras merupakan limbah yang berasal dari proses penyucian beras yang akan dimasak (Wardiah, 2013). Air leri banyak mengandung unsur dan senyawa yang bermanfaat bagi pertumbuhan jamur tiram seperti karbon, nitrogen, vitamin (B1, B3, B5, B7), dan mineral (Kalsum dkk., 2011). Menurut penelitian terdahulu dari Handiyanto $d k k$. (2013), air leri dapat meningkatkan pertumbuhan miselium jamur tiram putih pada biakan murni. Ketersediaan air leri juga cukup mudah untuk diperoleh. Pusat Data dan Sistem Informasi Pertanian (2015) menunjukkan ketersediaan dan produksi padi di Indonesia 
pada tahun 2010-2014 dengan pertumbuhan rata-rata mencapai $1,64 \%$ dan jumlah tertinggi sebesar 71.281.000 ton pada tahun 2013 . Penggunaan dan ketersediaan beras juga memiliki rata-rata pertumbuhan yang serupa, yaitu $1.66 \%$ pada tahun $2010-2014$. Olehnya itu, peneliti tertarik meneliti pemberian media tanam air leri dan larutan glukosa, serta intensitas cahaya yang bervariasi untuk pertumbuhan miselium jamur tiram putih di Tangerang.

\section{METODE}

Penelitian dilakukan di Kota Tangerang. Bag log jamur yang digunakan adalah F2 yang diperoleh dari pedagang jamur tiram putih di daerah Curug.

Pembuatan Kumbung Jamur. Rak besi dibuat 2 tingkat dengan masing-masing tingkat mempunyai 5 kardus yang disusun secara horizontal. Masing-masing kardus mempunyai luas alas $20 \mathrm{~cm} \times 20 \mathrm{~cm}$ dengan tinggi $30 \mathrm{~cm}$ (Gambar 1).

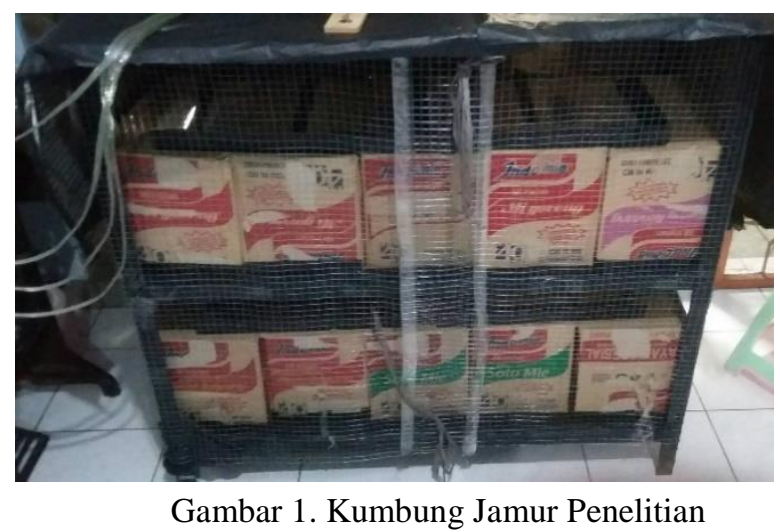

Pembuatan Air Leri dan Larutan Glukosa. Air leri yang digunakan dibuat dengan perbandingan 1:1. Sedangkan untuk glukosa digunakan perbandingan 1:3. Glukosa dilarutkan ke dalam akuades panas. Sementara air leri diperoleh dengan mencampurkan beras ke dalam akuades dan air limbah yang dihasilkan dari campuran tersebut diambil. Larutan glukosa dan air leri tersebut dimasukkan ke dalam botol sprayer dan diganti setiap 2 hari sekali. Sprayer disimpan di dalam kulkas sebagai pengawetan temporer untuk mencegah terjadinya fermentasi pada larutan glukosa dan ketengikan pada air leri.

Penyusunan Lampu. Lampu yang digunakan berjenis LED yang memiliki watt berbeda-beda, yaitu mulai dari 3, 5, 7 dan 9 . Perbedaan penggunaan lampu menghasilkan variasi intensitas cahaya secara berturut-turut yaitu 0 lux, $10^{3}$ lux, $2 \times 10^{3}$ lux, $3 \times 10^{3}$ lux, $4 \times 10^{3}$ lux. Lampu tersebut disusun dengan menggunakan rangkaian paralel. Total lampu yang digunakan sebanyak 8 buah.

Perlakuan Pada Penelitian. Setelah dibuka, permukaan bag log dibasahi dengan menggunakan nutrisi yang berbeda, yaitu 4 air leri, 4 larutan glukosa, dan 2 kontrol yang diberi akuades. Peneliti menyimpan kumbung di dalam rumah, untuk menjaga bibit jamur tiram putih terjaga kelembaban dan intensitas cahaya. Perlakuan ini adalah salah satu cara mereduksi penguapan.

Bag $\log$ F2 ditumbuhkan di dalam kardus. Setiap kardus masing-masing berisi 2 bag log jamur yang dibuka secara horizontal dan vertikal. Agar tidak diganggu oleh hama seperti tikus, semut, dan kecoa, kaki-kaki pada rak besi penampungan kumbung dilapisi dengan kapur ajaib dan dipasang kawat besi 3 meter di sekeliling rak besi. Pemberian nutrisi dilakukan setiap hari sebanyak 3 kali semprot pada pagi hari.

Perbedaan Suhu Ruangan Akibat Penyusunan Lampu LED. Lampu LED merupakan lampu yang tidak terlalu memancarkan panas, tetapi kardus tempat pemasangan lampu LED berukuran relatif kecil sehingga panas yang terpancar dari lampu lebih terasa dan mengakibatkan adanya perbedaan suhu dari variasi pemasangan lampu LED yang berbeda intensitas yang terlihat pada tabel 1 berikut. 
Tabel 1. Rata-Rata Suhu Ruangan

\begin{tabular}{cc}
\hline Ruang & Suhu \\
\hline Kontrol A, akuades & $30,03^{\text {abfg }}$ \\
\hline $\mathbf{1 0}^{\mathbf{3}}$ Lux, larutan glukosa & $30,65^{\text {abcdefg }}$ \\
\hline $\mathbf{2 x 1 0}^{\mathbf{3}}$ Lux, larutan glukosa & $30,98^{\text {bdefg }}$ \\
\hline $\mathbf{3 x 1 0}^{\mathbf{3}}$ Lux, larutan glukosa & $31,36^{\mathrm{bcde}}$ \\
\hline $\mathbf{4 x 1 0}^{\mathbf{3}}$ Lux, larutan glukosa & $31,23^{\text {bcdeg }}$ \\
\hline Kontrol B, akuades & $30,23^{\text {abfg }}$ \\
\hline $\mathbf{1 0}^{3}$ Lux, air leri & $30,40^{\text {abcfg }}$ \\
\hline $\mathbf{2 x 1 0}^{\mathbf{3}}$ Lux, air leri & $30,44^{\text {abcfg }}$ \\
\hline $\mathbf{3 x 1 0}^{\mathbf{3}}$ Lux, air leri & $30,57^{\text {abcefg }}$ \\
\hline $\mathbf{4 x 1 0}^{\mathbf{3}}$ Lux, air leri & $30,61^{\text {abcdefg }}$ \\
\hline
\end{tabular}

\section{HASIL}

Pada tahap pertumbuhan yang dilakukan selama 18 hari belum terlihat tubuh buah jamur yang tumbuh. Hasil penelitian menunjukkan bahwa intensitas cahaya sekitar $10^{3}$ lux adalah intensitas cahaya terbaik yang diberikan terhadap pertumbuhan miselium jamur tiram putih. Hal ini ditandai dengan semakin tebal dan putih miselium jamur tiram putih yang menutupi permukaan media tanam secara keseluruhan (Gambar 2). Nutrisi air leri dengan rasio perbandingan (1:1) yang diberikan kepada miselium jamur tiram putih lebih cepat tumbuh menyelimuti permukaan media tanam bag log dibandingkan dengan miselium yang diberi nutrisi larutan glukosa (1:3) dan kontrol.

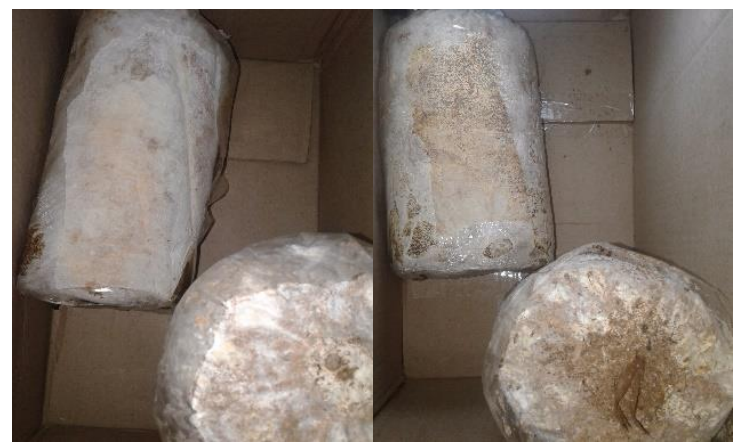

Gambar 2. Pertumbuhan miselium jamur tiram pada hari ke-5.

\section{PEMBAHASAN}

Pada intensitas cahaya yang tinggi seperti $2 \times 10^{3}$ lux, $3 \times 10^{3}$ lux, $4 \times 10^{3}$ lux muncul corak cokelat yang semakin banyak yang tidak dijumpai pada jamur tiram yang sehat. Intensitas cahaya jamur tiram saat pertumbuhan miselium dibutuhkan sekitar 501.500 lux (Hadiyanto, 2012). Berdasarkan pernyataan tersebut dapat diprediksi bahwa bag log jamur tiram yang tumbuh lebih dahulu adalah bag $\log$ yang diberi pencahayaan $10^{3}$ lux.

Cepatnya pertumbuhan miselium dengan pemberian air leri dapat dikarenakan air cucian beras atau air leri mengandung karbohidrat, protein glutein, dan vitamin yang tinggi seperti niasin, riboflavin, dan tiamin, serta mineral seperti $\mathrm{Ca}, \mathrm{Mg}$, dan Fe (Chethana et al., 2011) yang diperlukan untuk pertumbuhan jamur tiram putih. Bag log jamur tiram yang diberikan nutrisi tambahan glukosa tetap tumbuh baik walaupun tidak sebaik dengan pemberian nutrisi tambahan nutrisi air leri. Menurut Yuanita (2011), gula yang memengaruhi pertumbuhan jamur adalah Dglukosa. Glukosa dapat memberikan pertumbuhan maksimum bagi jamur, karena glukosa lebih mudah diubah menjadi suatu fosforilasi derivatif yang dapat masuk ke jalur sistem respirasi. Dengan kata lain D-glukosa, lebih efektif digunakan sebagai nutrisi bagi pertumbuhan jamur dibanding disakarida dan 
polisakarida lainnya. Meskipun glukosa mudah diserap dan menjadi salah satu kebutuhan nutrisi jamur tiram, tetapi dari pengamatan dapat terlihat bahwa nutrisi tambahan yang lebih dibutuhkan miselium untuk bertumbuh merupakan mikronutrien yang berasal dari air leri dibandingkan dengan nutrien dari pemberian glukosa.

Akan tetapi, jamur tiram yang tumbuh lebih baik dengan penambahan nutrisi air leri memungkinkan faktor lain yang mendukung pertumbuhannya seperti perbedaan suhu yang sedikit lebih rendah karena bag log yang ditambahkan air leri berada pada rak bawah sehingga memungkinkan keberadaan udara yang lebih dingin dibandingkan dengan rak atas yang dikelilingi suhu yang sedikit lebih tinggi.

\section{KESIMPULAN}

Setiap pemberian nutrisi yang berbeda pada setiap bag log mempengaruhi kualitas pertumbuhan miselium. Pertumbuhan miselium jamur tiram lebih cepat tumbuh pada pemberian nutrisi air leri dibandingkan dengan pemberian nutrisi glukosa.

Pencahayaan dengan intensitas berbeda juga mempengaruhi pertumbuhan miselium jamur tiram putih. Semakin tinggi intensitas cahaya lampu yang diberikan, percepatan pertumbuhan miselium jamur tiram putih semakin menurun, karena pada saat fase pembentukan miselium yang memenuhi bag log tidak terlalu membutuhkan intensitas cahaya yang tinggi atau bahkan sama sekali tidak membutuhkan cahaya sedangkan saat fase pembentukan tubuh buah jamur tiram putih membutuhkan intensitas cahaya yang agak terang.

\section{DAFTAR PUSTAKA}

Aliffahrana R. 2012. Respon Pertumbuhan Jamur Tiram Putih (Pleurotus ostreatus) pada Dua Kondisi Suhu dan Kelembaban Berbeda. [Tesis]. Bogor: Departemen Geofisika dan Meteorologi, Fakultas MIPA, Institut Pertanian Bogor. hal. 1-83.

Amelia F, Ferdinand J, Maria K, Waluyan MG, Sari IJ. 2017. Pengaruh Suhu dan Intensitas Cahaya Terhadap Pertumbuhan
Jamur Tiram di Tangerang. Biogenesis. vol $5 \quad$ (1): $1-6$. https://doi.org/10.24252/bio.v5i1.3426

Ayu P. 2016. Budidaya Jamur Tiram. 1st ed. Bandung: Putra Danayu Publisher. hal. 25.

Chethana SH, Pratap B, Roy S, Jaiswal A, Shruthi SD, Vedamurthy AB. 2011. Bioethanol Production from Rice Water Waste: A Low Cost Motor Fuel. Pharmacologyonline. vol 3: 125-134.

Hadiyanto. 2012. Pengaruh Lingkungan Terhadap Pertumbuhan Jamur Tiram. Makalah Seminar PTH 1507. Lampung: Program Studi Hortikultura. Jurusan Budidaya Tanaman Pangan. Politeknik Negeri Lampung.

Handiyanto S, Hastuti US, Prabaningtyas S. 2013. Kajian Penggunaan Air Cucian Beras Sebagai Bahan Media Pertumbuhan Biakan Murni Jamur Tiram Putih (Pleurotus ostreatus var. Florida). Prosiding Seminar Biologi FKIP UNS. vol: 10(2): 1-8.

Kalsum U, Fatimah S, Wasonowati C. 2011. Efektivitas Pemberian Air Leri Terhadap Pertumbuhan dan Hasil Jamur Tiram Putih (Pleurotus Ostreatus). Agrovigor. vol 4(2): 86-92.

Puspaningrum I dan Suparti. 2010. Produksi Jamur Tiram Putih (Pleurotus ostreatus) pada Media Tambahan Molase dengan Dosis yang Berbeda. Prosiding Seminar Biologi FKIP UNS. vol: 10(1): 1-8.

Puspitasari GG, Wignyanto, Dewanti BSD. 2014. Pemanfaatan Jamur Tiram Putih sebagai Tepung, Kajian Pengaruh Suhu dan Lama Pengeringan. [Skripsi]. Jurusan Teknologi Industri Pertanian FTP. Malang: Universitas Brawijaya.

Pusat Data dan Sistem Informasi Pertanian. 2015. Statistik Konsumsi Pangan. Jakarta: Kementerian Pertanian.

Sumarsih S. 2015. Bisnis Bibit Jamur Tiram. Revisi ed. Jakarta: Penebar Swadaya.

Tim Redaksi Trubus. 2010. Jamur Tiram Dua Alam: Dataran Rendah \& Dataran Tinggi. Jakarta: PT Niaga Swadaya. hal. 40. ISBN 97897993698881. 
Wahidah BF dan Saputra FA. 2015. Perbedaan Pengaruh Media Tanam Serbuk Gergaji dan Jerami Padi Terhadap Pertumbuhan Jamur Tiram Putih (Pleurotus ostreatus). Biogenesis. vol 3(1): 11-15. https://doi.org/10.24252/bio.v3i1.560.

Wardiah, Linda dan Rahmatan H. 2014. Potensi Limbah Air Cucian Beras Sebagai Pupuk Organik Cair Pada Pertumbuhan
Pakchoy (Brassica rapa L.). Jurnal Biologi Edukasi. vol 6(1): 34-38.

Yuanita L. 2011. Pengukuran Kadar Protein, Lemak, Karbohidrat, dan Air untuk Penentuan Usia Panen Terbaik Ditinjau dari Segi Nutrisi dan Ekonomi pada Jamur Tiram Putih. [Skripsi]. Medan: Departemen Kimia, Fakultas MIPA, Universitas Sumatera Utara. 